\title{
Research on the Influence of International MOOCs on College English Curriculum in China
}

\author{
Qing Song \\ School of Foreign Languages, Kunming University, Kunming, China \\ 932821517@qq.com
}

Keywords: MOOCs, large-scale open online courses, college English, curriculum design

\begin{abstract}
College English is the single subject with the highest percentage of colleges and universities in China, and it has always been the experimental field for teaching reform. With the popularization of MOOCs, Chinese college English teaching faces new challenges. A large number of international non-language professional MOOCs are on the line. These courses are equivalent to "all-English major courses" established by some colleges and universities in our country. Based on this, this paper analyzes the basic situation of international MOOCs, and then discusses the challenges and opportunities brought by MOOCs to college English teaching in China, in order to provide some help and guidance for the development of MOOCs in China.
\end{abstract}

\section{Introduction}

College English is the single subject with the highest percentage of colleges and universities in China, and it has always been the experimental field for teaching reform [1]. The "Course Requirements for College English Teaching" (namely "Course Requirements") promulgated in 2007 proposes the implementation of "University English Teaching Models Based on Computers and Classrooms" [2]. According to the characteristics of English language, students will be motivated through multimodal presentation methods. Sensory participation in language learning improves learning efficiency. The Ministry of Education has set up a special subject for college English teaching reforms to guide colleges and universities to implement the "computer-based and classroom-based college English teaching model," and comprehensively promote the integration of information technology and college English courses.

In 2012, international MOOCs quickly emerged, known as the "first year of international MOOCs," and the world's top university teacher courses are free to learners worldwide [3]. Many universities directly put on-campus courses on the Internet, and global learners can learn the classic courses of elite schools free of charge. The courses cover various fields of natural sciences and humanities and social sciences [4]. In 2013, it was known as the first year of Chinese MOOCs. Chinese universities joined the international MOOCs camp and started building their own MOOCs.

\section{International MOOCs Overview}

The MOOCs were created after Canadian educators George Siemens and Stephen Downes completed the autumn online course CCK08 in 2008. MOOCs have cMOOCs and xMOOCs, cMOOCs appear earlier, and xMOOCs started in 2011 [5]. In 2011, 160,000 learners from all over the world participated in the introduction of artificial intelligence by Sebastian Thrun, a professor at Stanford University. After the course, he resigned from teaching positions and founded Udacity, namely University + audacity, to build the first MOOCs network platform. He predicts that 10 years later, only 10 universities in the world will implement higher education. Udacity is one of them. Shortly thereafter, his colleagues Andrew Ng and Daphne Koller decided to open a profit-oriented company, Coursera. Subsequently, Harvard University and MIT each invested US\$30 million to create a non-profit edX MOOCs platform. Udacity, Couresera, edX are called MOOCs troika, and the three major platforms provide courses mainly xMOOCs. 
Currently, the MOOCs platform also includes Openuped in Europe, XuetangX in Tsinghua University in China, Iversity in Germany (the first institution to provide credits for European Credit Transfer and Cumulative Systems), and Futurelearn in the United Kingdom (which can be accessed via mobile phones, tablets, and Computer multi-terminal access), Australia's Open2Study (free from registration, learning materials, no hidden expenses). China's "MOOCs Academy" initiated by the "Fruit Shell Network" aggregates all international MOOCs under the "Courses" section of the website. Learners do not need to visit the above platforms to find courses. One-stop access to the "MOOCs Academy" is understood. The development of MOOCs is very rapid. As of 2016, only the Coursera platform registrants have reached more than 22 million people, from 190 countries, and 59 million people have participated in the course discussions, and the most popular single course enrollment has reached 240,000.

The construction of MOOCs in China is booming. Peking University, Tsinghua University, Shanghai Jiaotong University, etc. have started classes on the course platforms such as School Online, edX and Coursera, and are open to the world. On July 9, 2013, Shanghai Jiaotong University announced that it will build a platform for Chinese "Music" with 11 universities including Peking University, Tsinghua University and Fudan University. Then, on July 25, Peking University signed a contract with DeTao Group to jointly build the Peking University-DeTao MOOCs teaching platform. There are currently 10 courses on the MOOCs platform, the EWANT education open education platform jointly developed by Southwest Jiaotong University and Taiwan's Hsinchu Jiaotong University, Shanghai Jiaotong University, Xi'an Jiaotong University and Beijing Jiaotong University.

\subsection{MOOCs Characteristic Analysis.}

It is generally a free and open course for international learners from international prestigious universities. Its teaching style is similar to the class teaching system, but the class is extended to cyberspace. The whole earth is a giant classroom. Its main features are as follows: 1) The curriculum is time-sensitive (General course 2-12 weeks, after many MOOCs are over, unregistered persons cannot access the course); 2) Every week, there are homeworks, learners need to complete within the specified time. And the peer evaluation is used; 3) The curriculum is highly interactive (teacher interaction with learners, video and learner interaction, learner interaction); 4) Provide students learning files; 5) Complete the course and a person who has achieved a certain level of achievement is awarded a statement of accomplishment. In comparison, national fine courses, video open classes, and resource sharing classes are inferior to the "teaching" function.

In addition, there are three key features of MOOCs: 1) Micro-video; 2) Automatic scoring system, which can minimize the workload of professors involved in job evaluation; 3) Learners' forums to answer each other's questions and take advantage of collective wisdom. Micro video is generally controlled within 15 minutes, and questions will be inserted for the learners to answer during video playback. It is a bit like a game. The learner can try to answer multiple times until the answer is correct. The general system will give a corresponding explanation. This function, on the one hand, prevents students from thinking about desertification, and on the other hand helps learners digest teaching content. In addition, the speech rate of the video can be adjusted, and the speech rate is generally selected between 1-2. All MOOCs videos have English subtitles and some courses have multilingual subtitles.

\subsection{Content Analysis of International MOOCs: Take Coursera as an Example.}

The Coursera platform is currently the most popular MOOCs platform. As of December 15, 2016, the platform has built a total of 575 courses involving 25 categories including arts, biology, chemistry, education, social sciences, statistics and data analysis, and teacher education. The platform currently offers a total of 12 language courses, $84.3 \%$ of which are English courses ( as shown in Table 1), followed by Chinese and French, 28 and 19 respectively.

The author has organized 486 English courses offered by the Coursera platform, including 90 humanities courses, 68 Social Sciences courses, and 67 health \& society courses. There are 63 courses in Biology \& Life Sciences (as shown in Table 2). These courses are mainly open to 
undergraduate students and are based on basic courses. This is a large-scale self-selected supermarket course that can meet the needs of most learners and the number of courses is still increasing. The classification of courses is more specific. For example, Computer Science has been subdivided into Artificial Intelligence, Software Engineering, Systems \& Security, and Theory of Computer Science.

Table 1. Coursera Platform MOOCs Course

\begin{tabular}{|c|c|c|}
\hline Language & Number of courses & Percentage (\%) \\
\hline English & 486 & 84.3 \\
\hline Chinese & 28 & 4.9 \\
\hline French & 19 & 3.3 \\
\hline Spanish & 13 & 2.3 \\
\hline Russian & 13 & 2.3 \\
\hline Portuguese & 6 & 1.0 \\
\hline Turkish & 4 & 0.7 \\
\hline German & 2 & 0.3 \\
\hline Ukrainian & 2 & 0.3 \\
\hline Other & 3 & 0.5 \\
\hline
\end{tabular}

Table 2. Coursera course platform course classification and quantity

\begin{tabular}{|c|c|c|c|}
\hline Catalogue & No. & Catalogue & No. \\
\hline Arts & 22 & Health \& Society & 67 \\
\hline $\begin{array}{l}\text { Biology \& Life } \\
\text { Sciences }\end{array}$ & 63 & Humanities & 90 \\
\hline $\begin{array}{c}\text { Business \& } \\
\text { Management }\end{array}$ & 59 & Information, Tech \& Design & 44 \\
\hline Chemistry & 16 & Law & 10 \\
\hline $\begin{array}{l}\text { CS: Artificial } \\
\text { Intelligence }\end{array}$ & 27 & Mathematics & 33 \\
\hline $\begin{array}{l}\text { CS: Software } \\
\text { Engineering }\end{array}$ & 25 & Medicine & 59 \\
\hline $\begin{array}{l}\text { CS: Systems \& } \\
\text { Security }\end{array}$ & 21 & Music, Film, and Audio & 23 \\
\hline CS: Theory & 24 & Physical \& Earth Sciences & 18 \\
\hline $\begin{array}{l}\text { Economics \& } \\
\text { Finance }\end{array}$ & 52 & Physics & 23 \\
\hline Education & 59 & Social Sciences & 68 \\
\hline $\begin{array}{l}\text { Energy \& Earth } \\
\text { Sciences }\end{array}$ & 21 & Statistics and Data Analysis & 31 \\
\hline Engineering & 34 & $\begin{array}{c}\text { Teacher Professional } \\
\text { Development }\end{array}$ & 40 \\
\hline Food and Nutrition & 15 & & \\
\hline
\end{tabular}

\section{MOOCs Challenge to College English Teaching in China}

With the popularization of MOOCs, Chinese college English teaching faces new challenges. On the one hand, a large number of international non-language professional MOOCs (English as a teaching language) are being put on line successively. These courses are equivalent to "all-English major courses" opened by some colleges and universities in our country. On the other hand, the British Culture Division announced that it is collaborating with FutureLearn to build a large-scale open English course to help people improve their English. These courses are based on the extensive support and assessment experience of the British Culture Department over the years for global 
students and teachers. The first courses are 2014 is open to the world. The new English language MOOCs will enable global learners to use English for higher education and communicate more effectively in English.

\subsection{Challenge College English Teaching Quality.}

From 9th October to 16th of October 2016, China Shell conducted a large-scale questionnaire survey on Chinese users, with 6116 questionnaires retrieved and 5981 valid questionnaires. Of these, 2,440 participated in MOOCs. More than $80 \%$ of the learners have a bachelor degree or above (including students), with $55.54 \%$ students and $40.34 \%$ working staff. Only $6 \%$ of the students completed the entire course and $67 \%$ of the students did not complete one. The factors that hinder learners from completing the course include: "limited time to invest" (59\%), "lack of perseverance" (55\%), "language barrier” (55\%), and "inconsistent curriculum content with expectations” (22\%) , "language barriers" and "lack of perseverance" are tied for second place.

On the one hand, MOOCs challenge the quality of personnel training in universities in China. Many university students in our country fail to learn the language requirements of the international MOOCs after completing the college English course. The "Course Requirement" proposes to cultivate students' language comprehensive abilities. The students' comprehensive use of language skills is still not high enough to withstand the social test. On the other hand, MOOCs are typical student-centered instructional design courses that directly challenge the teacher-centered college English teaching model in China. MOOCs enhance the quality of teaching and create high-quality foreign language courses by creating a full English learning environment, providing classic learning resources, implementing teacher-student online interaction, and live and online instant interaction.

\subsection{Challenge College English Course Content.}

The above questionnaire did not further investigate why "language barriers" are one of the main factors that hinder students from completing MOOCs learning. MOOCs course content consists of: 1) Micro-video, 2) Designated reading of documents, 3) Participation in forum discussions, and 4) Completion of corresponding assignments. Language barriers can occur at any point. Learners may not understand videos, read articles or complete assignments.

Our country's orientation to college English is to cultivate students' comprehensive English application skills, especially their listening and speaking skills, so that they can effectively communicate in English in the future in their studies, work, and social interactions, and at the same time enhance their self-learning ability and improve their comprehensiveness. Under normal circumstances, university English in general colleges is mainly composed of "Comprehensive English" and "Viewing and Listening", and it focuses on cultivating students' humanistic qualities in content selection. The training of individualized learning needs of students is obviously insufficient and affects the follow-up development of students. MOOCs are different. There are 486 English courses on the Coursera platform, involving multiple majors, and the number of courses is increasing. The MOOCs curriculum is also importantly positioned as a free non-credit program, which undoubtedly poses a challenge to the monotonous, obscure and authoritative credit class.

\subsection{Challenge College English Assessment.}

The "Course Requirements" proposes that "the assessment of student learning is divided into formative assessment and final assessment." However, due to the peculiarities of college English as a public basic course, many university English teachers in ordinary universities and colleges are assigned to several classes at the same time. The number of students in each class is large, the quality of process evaluation is not high, and the final exam is necessary. Weighing the pass rates of students throughout the year, there is a clear lack of deterrence in English learning for students.

In addition, the employer's main criterion for judging students' English proficiency is the grades 4 and 6 exams. Students spend a lot of time preparing for grades 4 and 6, mechanically recite words, do reading comprehension, and practice standard listening. Once put into the real context, students do not respond completely. Classmates who are accustomed to the 4th and 6th grades of hearing are intent on MOOCs. Due to the lack of financial resources, material resources, and manpower, the 
large-area oral test is not implemented at present and the students' listening and speaking skills are cultivated. The ability to "say" is difficult to implement.

\section{MOOCs Brings Opportunities to College English Teaching in China}

The biggest advantage of MOOCs is that the famous teacher's courses are freely shared globally, so that learners can learn the lessons step by step. Students who have spared no time in learning can also learn the courses they are interested in, complete their homework, participate in global online community discussion courses, and exchange their own learning experiences. In today's increasingly difficult university students' attention to English at the university, MOOCs offer opportunities for college English teaching in China:

\subsection{Adjust Classroom Teaching Content According to Learners' MOOCs Learning Situation.}

Many learners fail to complete international MOOCs learning due to language barriers. This has once again made a wake-up call for English teaching in China. One of the characteristics of MOOCs is to allow learners to learn from their own pace. However, Chinese students and graduates are unable to complete MOOCs learning because of language barriers, indicating that English teaching in our country needs to be improved. On the one hand, it is necessary for us to answer questions to students in the classroom, to solve the problems encountered by students in the process of learning MOOCs; on the other hand, we need to find out the specific language barriers that students have encountered in the process of learning MOOCs through investigation and study, and give appropriate strengthening in the course of classroom teaching. In addition, as MOOCs' evaluation of homework is achieved mainly through peer feedback, students expect their teachers to be able to evaluate their work, not all from their peers.

\subsection{Rely on International MOOCs to Encourage Students to Learn College English.}

Teachers can seize this opportunity to encourage students to test their English proficiency through international MOOCs learning, develop demand oriented language learning, and stimulate students' interest in college English. Students will learn the problems encountered in the process of MOOCs, bring them to class, solve them through peer consultation, or solve them through consulting teachers.

\subsection{Adjust the College English Curriculum System Appropriately According to the Needs of MOOCs Curriculum.}

In recent years, there have been four calls for the reform of the content of college English teaching in China. Some scholars believe that the content of college English courses should be for ESP and academic English. Some scholars believe that the content of college English curriculum should be general education English, and cultivate students' humanistic quality and cross-cultural communicative competence. The main reason for the emergence of multiple claims is very much related to the different schools of experts. We can consider setting up a college English curriculum system combining "general English + college English follow-up" according to the specific circumstances of the school. Colleges and universities can conduct research on students who study MOOCs in the University, and adjust the curriculum system according to students' needs.

\subsection{Improve English Language Proficiency of Students by Leveraging International MOOCs.}

Through the study of international MOOCs, Chinese learners can not only test their language level, but also improve their language level, and improve their professional knowledge or humanistic quality.

Taking the Coursera platform as an example, learning any one of the 486 English courses requires the learners to use English as the only language (although some courses provide Chinese subtitles for the teaching video), complete the homework in English, and participate in the forum in English. In the course of the whole course of learning, the learner has a kind of place in English. The more MOOCs courses the learners have, the faster their English level will improve. In order to 
understand the content of the course, the learner needs to watch the video recordings repeatedly. In order to complete the homework, the learner has to gnaw on the English literature, read the work of the companion and give feedback, participate in the community discussion and browse English posts. In the whole learning process, learners are experiencing "real English", thinking in English and communicating in English, and the instrumentality of English has been fully demonstrated.

\section{Conclusion}

MOOCs brings challenges to our college English teaching as well as opportunities. MOOCs does not revolutionize higher education, but advances the existing educational paradigm and educational practice. MOOCs will further supplement and improve rather than replace the institutions of higher education. Reconstructing the college English curriculum system can more scientifically set up a reasonable curriculum system for different types of universities in China, and better integrate with the internationalization of higher education. Reconstructing the college English curriculum system also embodies the deep integration of the education information technology and foreign language courses in the MOOCs era. While reconstructing the college English curriculum system, we can not ignore that international MOOCs itself is a large comprehensive "course supermarket". Learners can choose their own courses free of charge in this supermarket, and can actively introduce international MOOCs for their own use and improve the quality of college English teaching.

\section{References}

[1] Wilson L, Gruzd A. MOOCs-international information and education phenomenon? [J]. Bulletin of the Association for Information Science \& Technology, 2015, 40(5):35-40.

[2] Pujar S M, Tadasad P G. MOOCs-an opportunity for international collaboration in LIS education: A developing country’s perspective [J]. New Library World, 2016, 6:360-373.

[3] Stratton C, Grace R. Exploring linguistic diversity of MOOCs: implications for international development[C]// Asis\&t Meeting: Creating Knowledge, Enhancing Lives through Information \& Technology. American Society for Information Science, 2016:71.

[4] Stratton C, Grace R. Exploring linguistic diversity of MOOCS: Implications for international development $[\mathrm{J}]$. Proceedings of the Association for Information Science \& Technology, 2016, 53(1):1-10.

[5] Kanwar A, Mishra S. The impact of OER and MOOCs on ODL: an international perspective [J]. Slovenian Veterinary Research, 2015, 47406(2):57-64. 